\title{
Professional Stressors in Prison Officers: a Cross-Sectional Study
}

\author{
Vesna M Paleksić ${ }^{1}$
}

\section{Abstract}

Background/Aim: The aim of this study was to analyse the stressors on prison officers' workplace in facilities of closed and semi-open type and their differences and the interconnection between specific sociodemographic variables (sex, age, marital status, exposed working experience, education level) and stressors on workplaces. Methods: The cross-sectional study included 330 prison officers, between 19 and 65 years of age, who have been divided in two groups depending on the security level of the facility (semi-open and close facility type). The research was conducted during 2015, using the following questionnaires: sociodemographic questionnaire, the organisational police stress questionnaire (PSQ.org) and the operational police stress questionnaire (PSQ.op).

Results: The results have shown significantly higher load with organisational and operative stress in facilities of closed type $(\mathrm{p}<0.001)$ and that in both groups operative stress sources were slightly more represented than the organisational. The intensity of stress ranged from low to medium. Higher intensity of organisational stress was perceived regarding stressors related to work appreciation, than in regard to sources related to logistic support, while the lowest intensity of stress was in regard to interpersonal relations in the organisation. In closed facilities, divorced prison officers and those who were separated from their families for a longer time have experienced higher stress intensity. Total work experience and age of prison officers had a moderate and mild effect, respecitively, on organisational stressors in higher security facilities. "Fatigue", "traumatic event" and "favouritism" were the most important stressors. Conclusion: The prison officers are exposed to stress of low to medium intensity, the operational stress sources being more represented then organisational. In higher security facilities total work experience and age had an influence on organisational stressors.

Key words: Prisons; Stress, psychological; Workplace; Occupational stress; Cross-sectional studies.

\section{Introduction}

There are five groups of factors that influence stress on the workplace: (1) the personality of the employee, (2) the conditions on the workplace, (3) the demands of the workplace, (4) the organisation of the workplace and (5) social environment and life conditions (family problems, living and material conditions, social and society changes, sickness, sudden life events). ${ }^{1}$
(1) Institute for Occupational Health and Sports of the Republic of Srpska, Banja Luka, the Republic of Srpska, Bosnia and Herzegovina.

Correspondence:

VESNA M PALEKSIĆ

M: +387 65561490

E: vesna.paleksic@hotmail.com

\section{ARTICLE INFO}

Received: 23 December 2019 Revision received: 28 July 2020 Accepted: 29 July 2020 
security with highly sophisticated video-surveillance and similar equipment. Beside the technical equipment and technical security, these types of facilities also have a high level of physical security and departments for special surveillance. Semi-open facilities usually have some elements of external security and inner structure as closed ones (often seen are high walls and wire), but the internal structure is normally less strict. Aggression inside the facility is less frequently demonstrated, the interpersonal problems between the staff and the prisoners are not very expressed. Open prison facilities are defined as facilities in which there are no obstacles for the escape of prisoners, there are no walls, bars nor armed security staff. Specialised facilities can be juvenile prisons, specialised hospitals for medical treatment of prisoners, psychiatric facilities for mentally disturbed prisoners and similar. In penal-correctional facilities there are by rule organisational units for security issues, re-education, health protection, employment of prisoners, as well as units for general and common matters. ${ }^{2}$ The security staff is made of prison officers (prison guards), who are armed, uniformed and of same sex as prisoners. In the Republic of Srpska there are six prison facilities of closed or semiopen types.

One of the first empirical stress evaluation studies on staff in prison facilities determined that, on average, prison staff had higher blood pressure than the inmates. ${ }^{3}$ Several studies confirmed that stressors among prison staff can be divided into two broader categories: problems with prisoners and problems with management (operative and organizational, respectively). ${ }^{4-6}$ In the research done by Rutter and Fielding it was concluded that stress connected with the inmates had biggest influence on the prison officers' health ${ }^{7}$, while other research indicated management as the most important stress source. ${ }^{5,8}$ In a different research it was determined that prison staff, especially in prisons with a stricter regime, more often suffered from mental illnesses connected to stress. ${ }^{9}$ In the literature there are consistent findings that the organisation, oversight, support between the colleagues, problems regarding working roles, ambiguous, unclear or conflicting roles (organisational stressors) are the most important sources of stress. ${ }^{8,10-12}$ However, the results in the literature are not consistent in regard to the influence of the sociodemographic factors (sex, age, work experience, marital status, education) on the stress of prison officers. ${ }^{13,14}$
The goal of this study was to analyse the stressors in prison officers' workplace in facilities of closed and semi-open type and their differences and the interconnection between specific sociodemographic variables (sex, age, marital status, exposed working experience, education level) and stressors in the workplaces.

\section{Methods}

The research was designed as a cross-sectional study among 477 police officers aged 19 to 65 from 6 prison facilities in the Republic of Srpska with at least 12 months of working experience. It was performed during 2015, according to the Helsinki declaration and approved by the Ethics Committee of the Institute for Occupational Health and Sports of the Republic of Srpska. The author of the article conducted the interviews personally. Subjects were informed about the aim of study and questionnaires itself. Study was voluntary and anonymous.

Stratification according to security level in the penal-correctional facility was performed. Two groups were compared to each other: (1) prison officers from the facility of the closed type (in Banja Luka, Foča and Bijeljina) and (2) prison officers from facilities of the semi-open type (in Doboj, East Sarajevo and Trebinje). The main instrument of the study were questionnaires and participation that were voluntary and anonymous. A total of 330 questionnaires were completely filled with the response rate of $69.2 \%$. Sociodemographic questionnaire contains the main data on the respondents: sex, age, marital status, living conditions, workplace, total work experience, experience on the current workplace, education, working time, night work, habits of alcohol or tobacco consumption, use of sedatives and other drugs.

For the assessment of stress sources on the work place questionnaires of the authors McCreary and Thompson were used: The Organisational Police Stress Questionnaire (PSQ.org) and The Operational Police Stress Questionnaire (PSQ.op). ${ }^{15}$ PSQ.org contains 20 statements and is structured into three groups: (a) organisational stress sources in narrower sense (claims number: 1, 2, $3,4,5,6,7,8,11,14,18$ and 19), (b) stress sources regarding work appreciation (claims number: 
10, 12, 15, 16 and 17) and (c) logistic support (claims number: 9, 13 and 20). PSQ.op contains 20 claims with which stress sources related to direct prison officer's work and problems in social environment such as: night work, injury risk, health issues, social problems, social stigma and other, are assessed. Organisational and operative stress sources are rated with answers on numeric scales of Likert's type from 1 (not stressful) to 7 (very stressful). ${ }^{15}$

Statistical tests used are Kolmogorov-Smirnov test of normality of the distribution and $\chi^{2}$ or Fisher's test for comparison. The significance of the difference was analysed with the Mann-Whitney-U-Test and Student's t-test. For the comparison of three groups of respondents, parameter ANOVA with post hoc analysis and non-parameter ANOVA (Kruskal-Wallis-Test) were used. As the correlation measure Spearman's coefficient was used. The importance level for all statistical analyses was 0.05 for statistically significant difference and 0.01 for highly significant statistical difference. Statistical package IBM SPSS 17.0 was used.

\section{Results}

Out of 477 penal-correctional police officers, 330 (69.2\%) were included in the study: Banja Luka $97 / 131=74.0 \%$, Foča 76/129 $=58.9 \%$, Bijeljina $47 / 51=92.2 \%$, Doboj 27/66 = $40.9 \%$, East Sarajevo $51 / 65=78.5 \%$, Trebinje $32 / 35=91.4 \%$. The study included $312(94.5 \%)$ men and 18 (5.5\%) women, with the average age of $38.3 \pm 7.7$ years (minimum 22 and maximum 62 years of age). (Table 1).

In prison facilities of the closed type there were $220(67 \%)$ employees and 110 (33\%) in facilities of the semi-open type. Average age of prison officers in facilities of closed type was $38.6 \pm 7.8$ and in semi-open it was $37.7 \pm 7.3$ years. Women more often worked in facilities of semi-open type $(p<0.01)$, while employees in closed facilities more often lived apart from their families ( $p<0.05)$. Groups did not show any difference regarding other assessed parameters.

There are no significant differences between these two groups regarding the habits of alcohol,
Table 1: Main sociodemographic characteristics of respondents according to the type of penal-correctional facility

\begin{tabular}{|c|c|c|c|}
\hline $\begin{array}{l}\text { Assessed } \\
\text { Characteristics }\end{array}$ & $\begin{array}{l}\text { Closed } \\
\text { Facilities }\end{array}$ & $\begin{array}{l}\text { Semi-Open } \\
\text { Facilities }\end{array}$ & p-value \\
\hline Gender ( $\%$ men) & 97.3 & 89.1 & $\mathrm{p}<0.01$ \\
\hline Age (years: mean $\pm S D$ ) & $38.6 \pm 7.8$ & $37.7 \pm 7.3$ & $\mathrm{p}=0.29$ \\
\hline \multicolumn{4}{|l|}{ Marital status (\%) } \\
\hline single & 19.1 & 15.5 & \multirow[b]{6}{*}{$\mathrm{p}=0.38$} \\
\hline married & 73.2 & 80 & \\
\hline living with partner & 2.7 & 0.9 & \\
\hline divorced & 4.1 & 1.8 & \\
\hline widower/widow & 0.9 & 0.9 & \\
\hline living apart & 0.0 & 0.9 & \\
\hline \multicolumn{4}{|l|}{ Lifestyle (\%) } \\
\hline single & 5.9 & 2.7 & \\
\hline family with children & 60.5 & 71.8 & \\
\hline family without children & 7.3 & 4.5 & \multirow[b]{3}{*}{$\mathrm{p}=0.31$} \\
\hline single with children & 0.9 & 0.9 & \\
\hline with parents & 25.5 & 20 & \\
\hline \multicolumn{4}{|l|}{ Separation (\%) } \\
\hline no & 93.6 & 100 & \multirow[b]{3}{*}{$\mathrm{p}=0.03$} \\
\hline during the week & 3.6 & 0.0 & \\
\hline longer time & 2.7 & 0.0 & \\
\hline \multicolumn{4}{|l|}{ Education (\%) } \\
\hline apprenticeship & 13.2 & 11.8 & \multirow[b]{5}{*}{$\mathrm{p}=0.54$} \\
\hline high school & 60.5 & 63.6 & \\
\hline college & 4.1 & 5.5 & \\
\hline university & 22.3 & 18.2 & \\
\hline post graduate degree & 0.0 & 0.9 & \\
\hline Total (N) & 220 & 110 & \\
\hline
\end{tabular}

tobacco and sedative consumption, but there was a tendency for employees in facilities of closed type to use other drugs more often.

Prison officers in facilities of closed type longer commuted, their work experience on the current

Table 2: Main characteristics of respondents' jobs in two different types of penal-correctional facilities

\begin{tabular}{|c|c|c|c|}
\hline $\begin{array}{l}\text { Assessed } \\
\text { Characteristics }\end{array}$ & $\begin{array}{l}\text { Closed } \\
\text { Facilities }\end{array}$ & $\begin{array}{l}\text { Semi-Open } \\
\text { Facilities }\end{array}$ & p-value \\
\hline \multicolumn{4}{|l|}{ Working Time (\%) } \\
\hline full & 10.5 & 9.1 & \\
\hline shift & 11.9 & 15.5 & \\
\hline shift without weekends & 0.5 & 0.9 & \\
\hline shift without weekends and night work & 1.4 & 0.0 & \\
\hline shift of $12 \mathrm{~h}$ & 75.8 & 74.5 & $\mathrm{p}=0.62$ \\
\hline Weekly overtime work (h) & $3.8 \pm 4.1$ & $3.1 \pm 3.6$ & $\mathrm{p}=0.08$ \\
\hline Duration of commuting (h) & $0.8 \pm 1.3$ & $0.5 \pm 0.4$ & $p=0.00$ \\
\hline Total work experience (years) & $16.1 \pm 9.0$ & $16.4 \pm 8.4$ & $\mathrm{p}=0.13$ \\
\hline $\begin{array}{l}\text { Work experience on the } \\
\text { current workplace (years) }\end{array}$ & $8.0 \pm 6.6$ & $11.0 \pm 5.9$ & $p<0.01$ \\
\hline Total shift work experience & $12.3 \pm 8.0$ & $12.3 \pm 7.1$ & $p=0.91$ \\
\hline Total (N) & 220 & 110 & \\
\hline
\end{tabular}

Legend: Test: Mann-Whitney U-test, except for Working time: Chi-square test ( $\chi^{2}$ ); $h$ : hours 
Table 3: Organisational stress sources on workplace depending on the type of penal- correctional facility

\begin{tabular}{|c|c|c|c|c|}
\hline Organisational stressors & $\begin{array}{l}\text { Facility } \\
\text { Type }\end{array}$ & $\begin{array}{l}\text { Mean } \\
\text { value }\end{array}$ & SD & $\begin{array}{l}\text { p } \\
\text { (Mann-Whitney- } \\
\text { U- test) }\end{array}$ \\
\hline 1 Dealing with co-workers & $\begin{array}{l}\text { Closed } \\
\text { Semi-open }\end{array}$ & $\begin{array}{l}3.1 \\
2.7\end{array}$ & $\begin{array}{l}1.8 \\
1.6\end{array}$ & 0.03 \\
\hline $\begin{array}{l}2 \text { The feeling that different rules apply } \\
\text { to different people (eg, favouritism) }\end{array}$ & $\begin{array}{l}\text { Closed } \\
\text { Semi-open }\end{array}$ & $\begin{array}{l}4.7 \\
3.9\end{array}$ & $\begin{array}{l}5.2 \\
1.7\end{array}$ & 0.02 \\
\hline $\begin{array}{l}3 \text { Feeling like you always have to prove } \\
\text { yourself to the organisation }\end{array}$ & $\begin{array}{l}\text { Closed } \\
\text { Semi-open }\end{array}$ & $\begin{array}{l}4.0 \\
3.1\end{array}$ & $\begin{array}{l}1.7 \\
1.7\end{array}$ & $0.00^{*}$ \\
\hline 4 Excessive administrative duties & $\begin{array}{l}\text { Closed } \\
\text { Semi-open }\end{array}$ & $\begin{array}{l}3.4 \\
2.8\end{array}$ & $\begin{array}{l}1.7 \\
1.6\end{array}$ & $0.00^{*}$ \\
\hline 5 Constant changes in policy/legislation & $\begin{array}{l}\text { Closed } \\
\text { Semi-open }\end{array}$ & $\begin{array}{l}2.8 \\
3.6\end{array}$ & $\begin{array}{l}1.6 \\
2.0\end{array}$ & $0.00^{*}$ \\
\hline 6 Staff shortages & $\begin{array}{l}\text { Closed } \\
\text { Semi-open }\end{array}$ & $\begin{array}{l}3.5 \\
3.1\end{array}$ & $\begin{array}{l}1.9 \\
1.8\end{array}$ & 0.08 \\
\hline 7 Bureaucratic red tape & $\begin{array}{l}\text { Closed } \\
\text { Semi-open }\end{array}$ & $\begin{array}{l}3.4 \\
2.6\end{array}$ & $\begin{array}{l}1.8 \\
1.5\end{array}$ & $0.00^{*}$ \\
\hline 8 Too much computer work & $\begin{array}{l}\text { Closed } \\
\text { Semi-open }\end{array}$ & $\begin{array}{l}2.2 \\
1.8\end{array}$ & $\begin{array}{l}1.5 \\
1.2 \\
\cdots .2\end{array}$ & 0.03 \\
\hline 9 Lack of training on new equipment & $\begin{array}{l}\text { Closed } \\
\text { Semi-open }\end{array}$ & $\begin{array}{l}2.9 \\
2.5\end{array}$ & $\begin{array}{l}1.8 \\
1.7\end{array}$ & 0.07 \\
\hline $\begin{array}{l}10 \text { Perceived pressure to volunteer } \\
\text { free time }\end{array}$ & $\begin{array}{l}\text { Closed } \\
\text { Semi-open }\end{array}$ & $\begin{array}{l}4.3 \\
3.4\end{array}$ & $\begin{array}{l}1.9 \\
1.9\end{array}$ & $0.00^{*}$ \\
\hline 11 Dealing with supervisors & $\begin{array}{l}\text { Closed } \\
\text { Semi-open }\end{array}$ & $\begin{array}{l}2.7 \\
2.3\end{array}$ & $\begin{array}{l}1.7 \\
1.7\end{array}$ & 0.03 \\
\hline 12 Inconsistent leadership style & $\begin{array}{l}\text { Closed } \\
\text { Semi-open }\end{array}$ & $\begin{array}{l}3.5 \\
3.1\end{array}$ & $\begin{array}{l}1.9 \\
1.8\end{array}$ & 0.03 \\
\hline 13 Lack of resources & $\begin{array}{l}\text { Closed } \\
\text { Semi-open }\end{array}$ & $\begin{array}{l}3.6 \\
3.1 \\
3\end{array}$ & $\begin{array}{l}1.8 \\
1.6\end{array}$ & 0.04 \\
\hline $\begin{array}{l}14 \text { Unequal sharing of work } \\
\text { responsibilities }\end{array}$ & $\begin{array}{l}\text { Closed } \\
\text { Semi-open }\end{array}$ & $\begin{array}{l}3.8 \\
3.3\end{array}$ & $\begin{array}{l}1.9 \\
1.9\end{array}$ & 0.02 \\
\hline $\begin{array}{l}15 \text { If you are sick or injured your } \\
\text { co-workers seem to look down on you }\end{array}$ & $\begin{array}{l}\text { Closed } \\
\text { Semi-open }\end{array}$ & $\begin{array}{l}2.7 \\
2.1\end{array}$ & $\begin{array}{l}1.9 \\
1.4\end{array}$ & 0.01 \\
\hline $\begin{array}{l}16 \text { Leaders over-emphasise the } \\
\text { negatives }\end{array}$ & $\begin{array}{l}\text { Closed } \\
\text { Semi-open }\end{array}$ & $\begin{array}{l}3.3 \\
2.9\end{array}$ & $\begin{array}{l}1.8 \\
1.8\end{array}$ & 0.02 \\
\hline 17 Internal investigations & $\begin{array}{l}\text { Closed } \\
\text { Semi-open }\end{array}$ & $\begin{array}{l}3.3 \\
3.0\end{array}$ & $\begin{array}{l}1.8 \\
1.9\end{array}$ & 0.11 \\
\hline 18 Dealing the court system & $\begin{array}{l}\text { Closed } \\
\text { Semi-open }\end{array}$ & $\begin{array}{l}2.6 \\
2.5\end{array}$ & $\begin{array}{l}1.7 \\
1.7 \\
\cdots . .\end{array}$ & 0.39 \\
\hline $\begin{array}{l}19 \text { The need to be accountable for doing } \\
\text { your job }\end{array}$ & $\begin{array}{l}\text { Closed } \\
\text { Semi-open }\end{array}$ & $\begin{array}{l}3.3 \\
3.1\end{array}$ & $\begin{array}{l}1.8 \\
1.9\end{array}$ & 0.31 \\
\hline 20 Dealing the court system & $\begin{array}{l}\text { Closed } \\
\text { Semi-open }\end{array}$ & $\begin{array}{l}3.7 \\
2.9\end{array}$ & $\begin{array}{l}1.8 \\
1.7\end{array}$ & $0.00^{*}$ \\
\hline
\end{tabular}

Legend: In order to avoid the first-level-error, the correction of the statistical importance level for multiple comparisons was used: $p=0.05 / 40=0.001$, therefore ${ }^{*} p<0.001$

workplace was on average by three years longer than that of employees in institutions of the semiopen type; the two groups did not show any other differences in regard to other job characteristics (Table 2).

In the facilities of closed type, both organisational and operative stressors were statistically significant $(\mathrm{p}<0.01)$. Mean value for organisational stressors were 67.6 vs 57.3 (closed vs semi-open type), and for operative 69.8 vs 59.8 (Data not shown in the table).

Organisational stressors in narrower sense in facilities of closed type are in the domain moderate stressful (mean value 3.35) and in semiopen facilities in the domain not stressful (mean value 2.8 ). (Table 3 ). Highest mean value in the organisational stressors group was found for the stressor: "Feeling that different rules are applied for different persons, favouritism" (mean value = 4.7 and 3.9). A total of $19.5 \%$ of prison officers
Table 4: Operative stress sources on workplace depending on the type of penal-correctional facility

\begin{tabular}{|c|c|c|c|c|}
\hline Operative stressors & $\begin{array}{l}\text { Facility } \\
\text { Type }\end{array}$ & $\begin{array}{l}\text { Mean } \\
\text { value }\end{array}$ & SD & $\begin{array}{l}\text { p } \\
\text { (Mann-Whitney- } \\
\text { U- test) }\end{array}$ \\
\hline 1 Shift work & $\begin{array}{l}\text { Closed } \\
\text { Semi-open }\end{array}$ & $\begin{array}{l}3.4 \\
3.0\end{array}$ & $\begin{array}{l}1.9 \\
1.8\end{array}$ & 0.07 \\
\hline 2 Working alone at night & $\begin{array}{l}\text { Closed } \\
\text { Semi-open }\end{array}$ & $\begin{array}{l}3.7 \\
3.5\end{array}$ & $\begin{array}{l}1.9 \\
2.0\end{array}$ & 0.23 \\
\hline 3 Over-time demands & $\begin{array}{l}\text { Closed } \\
\text { Semi-open }\end{array}$ & $\begin{array}{l}3.8 \\
3.3\end{array}$ & $\begin{array}{l}2.0 \\
1.9\end{array}$ & 0.05 \\
\hline 4 Risk of being injured on the job & $\begin{array}{l}\text { Closed } \\
\text { Semi-open }\end{array}$ & $\begin{array}{l}3.5 \\
3.3\end{array}$ & $\begin{array}{l}1.9 \\
2.0\end{array}$ & 0.44 \\
\hline $\begin{array}{l}5 \text { Work related activities on days off } \\
\text { (e.g. court, community events) }\end{array}$ & $\begin{array}{l}\text { Closed } \\
\text { Semi-open }\end{array}$ & $\begin{array}{l}3.7 \\
3.3\end{array}$ & $\begin{array}{l}1.9 \\
1.8\end{array}$ & 0.14 \\
\hline 6 Traumatic events (e.g. death, injury) & $\begin{array}{l}\text { Closed } \\
\text { Semi-open }\end{array}$ & $\begin{array}{l}4.0 \\
3.8\end{array}$ & $\begin{array}{l}2.1 \\
2.0\end{array}$ & 0.59 \\
\hline $\begin{array}{l}7 \text { Managing your social life outside } \\
\text { of work }\end{array}$ & $\begin{array}{l}\text { Closed } \\
\text { Semi-open }\end{array}$ & $\begin{array}{l}3.0 \\
2.8\end{array}$ & $\begin{array}{l}1.7 \\
1.8\end{array}$ & 0.28 \\
\hline $\begin{array}{l}8 \text { Not enough time available to spend } \\
\text { with friends and family }\end{array}$ & $\begin{array}{l}\text { Closed } \\
\text { Semi-open }\end{array}$ & $\begin{array}{l}4.0 \\
3.6\end{array}$ & $\begin{array}{l}1.9 \\
1.8\end{array}$ & 0.07 \\
\hline 9 Paperwork & $\begin{array}{l}\text { Closed } \\
\text { Semi-open }\end{array}$ & $\begin{array}{l}3.7 \\
2.8\end{array}$ & $\begin{array}{l}1.9 \\
1.6\end{array}$ & $0.00^{*}$ \\
\hline 10 Eating healthy at work & $\begin{array}{l}\text { Closed } \\
\text { Semi-open }\end{array}$ & $\begin{array}{l}3.8 \\
3.5\end{array}$ & 2.1 & 0.22 \\
\hline $\begin{array}{l}11 \text { Finding time to stay in good physical } \\
\text { condition }\end{array}$ & $\begin{array}{l}\text { Closed } \\
\text { Semi-open }\end{array}$ & $\begin{array}{l}3.5 \\
2.8\end{array}$ & $\begin{array}{l}1.7 \\
1.8\end{array}$ & $0.00^{\star}$ \\
\hline 12 Fatigue (e.g. shift work, over-time) & $\begin{array}{l}\text { Closed } \\
\text { Semi-open }\end{array}$ & $\begin{array}{l}4.4 \\
3.6\end{array}$ & $\begin{array}{l}1.9 \\
1.8\end{array}$ & 0.01 \\
\hline $\begin{array}{l}13 \text { Occupation-related health issues } \\
\text { (e.g. back pain) }\end{array}$ & $\begin{array}{l}\text { Closed } \\
\text { Semi-open }\end{array}$ & $\begin{array}{l}3.6 \\
3.0\end{array}$ & $\begin{array}{l}2.0 \\
1.8\end{array}$ & 0.01 \\
\hline $\begin{array}{l}14 \text { Lack of understanding from family } \\
\text { and friends about your work }\end{array}$ & $\begin{array}{l}\text { Closed } \\
\text { Semi-open }\end{array}$ & $\begin{array}{l}3.2 \\
2.6\end{array}$ & $\begin{array}{l}1.8 \\
1.6\end{array}$ & 0.01 \\
\hline 15 Making friends outside the job & $\begin{array}{l}\text { Closed } \\
\text { Semi-open }\end{array}$ & $\begin{array}{l}2.7 \\
2.1\end{array}$ & $\begin{array}{l}1.8 \\
1.7\end{array}$ & $0.00^{\star}$ \\
\hline 16 Upholding a "higher image" in public & $\begin{array}{l}\text { Closed } \\
\text { Semi-open }\end{array}$ & $\begin{array}{l}2.7 \\
2.2\end{array}$ & $\begin{array}{l}1.6 \\
1.5\end{array}$ & 0.01 \\
\hline 17 Negative comments from the public & $\begin{array}{l}\text { Closed } \\
\text { Semi-open }\end{array}$ & $\begin{array}{l}3.0 \\
2.7\end{array}$ & $\begin{array}{l}1.7 \\
1.6\end{array}$ & 0.06 \\
\hline 18 Limitations to your social life & $\begin{array}{l}\text { Closed } \\
\text { Semi-open }\end{array}$ & $\begin{array}{l}3.1 \\
2.6\end{array}$ & $\begin{array}{l}1.5 \\
1.6\end{array}$ & 0.01 \\
\hline 19 Feeling like you are always on the job & $\begin{array}{l}\text { Closed } \\
\text { Semi-open }\end{array}$ & $\begin{array}{l}3.8 \\
2.9\end{array}$ & $\begin{array}{l}2.0 \\
1.8\end{array}$ & $0.00^{\star}$ \\
\hline $\begin{array}{l}20 \text { Friends / family feel the effects of the } \\
\text { stigma associated with your job }\end{array}$ & $\begin{array}{l}\text { Closed } \\
\text { Semi-open }\end{array}$ & $\begin{array}{l}3.3 \\
2.5\end{array}$ & $\begin{array}{l}1.8 \\
1.6\end{array}$ & $0.00^{*}$ \\
\hline
\end{tabular}

in closed facilities and $9.1 \%$ in the semi-open facilities have marked the question 10 ("Perceived pressure to volunteer free time") as the most stressful, that is with the grade 7 on Likert's scale. Operative stressors in facilities of closed type are in the domain moderate stressful (mean value 3.49) and in semi-open facilities in the domain not stressful (mean value 2.95) (Table 4). The highest mean value among respondents from closed facilities was found for the stressor: "fatigue, shift work, overtime work" (mean value $=4.4$ ). Among prison officers from facilities of semi-open type, the highest mean value in the group of operative stressors was found for the stressor "traumatic event" (mean value $=3.8$ ). A total of $19.5 \%$ of the respondents in closed facilities and $16.4 \%$ in semi-open facilities have marked the question 6 ("traumatic event") as the most stressful, that is with the grade 7 on Likert's scale.

Table 5. shows the correlation between the operative and organisational stress as dependent 


\begin{tabular}{|c|c|c|c|c|c|}
\hline \multirow{2}{*}{$\begin{array}{l}\text { Job Characteristics } \\
\text { and sociodemographic } \\
\text { variable }\end{array}$} & \multirow{2}{*}{ Stressor } & \multicolumn{2}{|c|}{ Closed Facilities } & \multicolumn{2}{|c|}{ Semi-Open Facilities } \\
\hline & & $\begin{array}{l}\text { Spearmann's } \\
\text { coefficient p }\end{array}$ & $\mathrm{p}$ & $\begin{array}{l}\text { Spearmann's } \\
\text { coefficient } p\end{array}$ & $\mathrm{p}$ \\
\hline \multirow{2}{*}{ Total Work Experience } & $\begin{array}{l}\text { Organisational } \\
\text { stressors }\end{array}$ & 0.51 & 0.00 & 0.17 & 0.08 \\
\hline & $\begin{array}{l}\text { Operational } \\
\text { stressors }\end{array}$ & 0.13 & 0.6 & 0.17 & 0.08 \\
\hline \multirow{2}{*}{$\begin{array}{l}\text { Work experience on the } \\
\text { current workplace }\end{array}$} & $\begin{array}{l}\text { Organisational } \\
\text { stressors }\end{array}$ & 0.13 & 0.06 & 0.03 & 0.73 \\
\hline & $\begin{array}{l}\text { Operational } \\
\text { stressors }\end{array}$ & 0.12 & $0.03^{*}$ & 0.12 & 0.22 \\
\hline \multirow{2}{*}{ Working hours } & $\begin{array}{l}\text { Organisational } \\
\text { stressors }\end{array}$ & -0.03 & 0.70 & 0.13 & 0.19 \\
\hline & $\begin{array}{l}\text { Operational } \\
\text { stressors }\end{array}$ & 0.01 & 0.26 & 0.13 & 0.17 \\
\hline \multirow{2}{*}{ Age } & $\begin{array}{l}\text { Organisational } \\
\text { stressors }\end{array}$ & 0.15 & 0.02 & 0.12 & 0.20 \\
\hline & $\begin{array}{l}\text { Operational } \\
\text { stressors }\end{array}$ & 0.14 & 0.04 & 0.11 & 0.25 \\
\hline
\end{tabular}

Table 5: Correlation between age and job characteristics and perceived stress in closed and semi-open facilities variables and the sociodemographic characteristics of respondents as independent variables (univariant analysis).

Sex, age, work experience, work experience in the current position did not have influence in facilities of semi-open type on operative stressors. Total work experience and age had a moderate positive influence on organisational stressors and age had a very low positive influence on operative stressors in facilities of closed type. Other variables that were examined did not corelate with stressors in both types of facilities.

Variant analysis has determined that there is a statistically significant difference between divorced and single respondents in closed facilities in regard to organisational stressors $(p=0.009)$ and in regard to operational stressrs ( $\mathrm{p}=0.045)$, as well as between the divorced and married respondents in regard to experience of organisational stressors $(p=0.02)$, the divorced experiencing higher stress.

\section{Discussion}

The results of this study have shown that prison officers in the Republic of Srpska are exposed to a larger number of professional stressors whose intensity was ranging from „moderate stressful“ to "not stressful" and that sociodemographic characteristics did not significantly impact the perception of stress in the workplace. Moderate positive correlation in higher security facilities was found between the total work experience and organisational stressors and mild correlation between the age and the organisational stressors.

The results of this study have shown that in closed facilities divorced prison officers experience higher intensity of organisational and operative stress when compared to singles and higher intensity of organisational stress when compared to married participants. In semi-open facilities marital status did not have any influence on stress experience. Also, the research found that respondents who were separated from their families for a longer time experience higher stress intensity when compared to those not separated. In semi-open facilities it was found that prison officers with high alcohol consumption experienced higher stress intensity. Alcohol can be an attempt to "cure stress", but also the awardeness of excessive alcohol usage can also be a source of stress itself. ${ }^{13,14}$ No difference in stress experience was found in regard to education level, in both types of facilities. Most other studies, although not consistent, also show that there is no significant interconnection between the stress experience and sex, age, marital status, work experience and work satisfaction of employees in prison facilities. ${ }^{4,6,13,14}$ It should be noted though, that some researchers have found that female and older employees in prisons experience stress of higher intensity. ${ }^{13,14}$

According to Morgan et al ${ }^{16}$ prison staff in prisons of higher security experience stress of higher intensity, while Sudipto and Avdi ${ }^{17}$ did not find that difference. This problem occupied many researchers, but the results are not consistent. In this research it was found that stress intensity was somewhat higher in closed facilities (higher 
security), in the domain of "moderately stressful" and in semi-open facilities in the domain of "not stressful". In facilities of closed type there was a statistically much higher load both with organisational and operational stressors when compared to the semi-open facilities $(\mathrm{p}<0.01$, statistically highly important difference) was found. Besides that, operative stress sources are in both groups somewhat more represented than organisational, but this is of no statistical significance. The result of this study is in contrast to the studies from Europe and USA, which emphasise organisational stressors, that is stressors related to interpersonal relationships in the organisation. ${ }^{7,8}$ There are consistent findings in the literature that support from the management, from the organisation and from colleagues, role problems, ambiguous, unclear and conflict loaded roles, the conflict work-family and dangers are the most important sources of stress. ${ }^{8,10-12}$ In the study on stress with prison employees in Ireland, Regan stated that prison employees experienced significant stress in the workplace and predictors of stress were problems with the management, concern for own safety, overload, overtime work, work-family conflicts. ${ }^{4}$

In our country and in countries of Eastern Europe which have gone through economic, political and social reforms, the value system is somewhat different then in developed western countries, so that the perception of important work stressors is also different. Besides that, a pre-selection of candidates based on health demands of the workplace is done in the Republic of Srpska before employment and for police officers this is regulated in separate regulations, so this can also be a factor for the lesser experience of stress intensity in work. In this way some of the differences in the results and specifics regarding our prison facilities can be explained.

In the research which was conducted in 2009, in the prison facility East Sarajevo (facility of semiopen type), $55 \%$ of prison officers have stated that they suffer from stress in their workplace and $41 \%$ have stated that shift and overtime work are the most important stress sources in work. ${ }^{18}$ These results are almost totally consistent with this research.

According to this research "fatigue due to overload, shift work, overtime work without compen- sation" is the most important stress source in facilities of closed type in the operative stressors group. In earlier research this stressor was marked as one of the most important stress sources, and its role remains important even today. ${ }^{4,19}$ In one English study overtime work, lack of support and appreciation were marked as significant stress sources in work. ${ }^{20}$ According to the results of an Israeli study, the most important stressors of prison officers are overtime work without compensation, low wages and a difficult job. ${ }^{21}$

"Traumatic event" is the most important stress source in the operative stressors group in facilities of semi-open type. Traumatic events can be a physical attack on the prison officer, injury or death of other persons, suicide of inmates, prison riots, conflicts between prisoners, fear of contagious illness while contacting secretion of sick or infected inmates and similar. In USA there were 113 deaths at work among prison officers from 1999 to 2008, the death rate being 2.7/100,000 a year.22 According to the report of US Justice Department from 2000, non-fatal incidents on 1,000 prison officers are higher than in any other profession apart from police officers. ${ }^{32}$ Lambert and Paoline have determined that perception of danger was the highest predictor of stress on work, ${ }^{24}$ and fear of illness the second most powerful predictor. ${ }^{25}$ The prison officers as well as the police officers confront the most violent, anti-social and problematic elements of the society and sometimes find themselves in life- threatening situations. This can lead to stress manifestations such as posttraumatic stress reactions, behavioural disorders, acute, chronic and permanent stress manifestations and health consequences. Prison staff working in prisons all over Texas showed that the perception of danger had the highest correlation with stress in work, while fear of sickness was in the second place. ${ }^{26}$

In this research the highest mean value in the organisational stressors group in prisons of closed and semi-open type was found for the stressor "favouritism". This finding is consistent with findings of other researchers. ${ }^{11,27}$ If in the same workplace the rules are not the same for all employees, the principle of justice is disturbed, and it comes to favouritism and not deserved privileges. This factor mirrors in situations when there is inequality in workload or in pay, then through the 
experience of injustice or betrayal, when there is no reward or promotion to match the achievements. Over this dimension self-respect is shown and self-value is confirmed. Due to impairment of the possibility to show own's abilities and to get appreciation, promotion or reward for those, there comes to frustration and insatisfaction. ${ }^{28}$ It is generally known that our society is suffering from corruption, nepotism and disturbed value system, which is a fertile ground for "injustice" and privileges in the workplace.

The advantage of this study is the representativity of the sample, which realistically describes the studied population. The study has a methodological limitation because it is designed as a cross-sectional study that shows the current state without changes in time and does not allow for conclusions on the direction of cause-and-effect connection. Apart from that, for the assessment of variables the method of self-report was used, which is subjective, and the possibility of wrong answers cannot be ruled out. According to the results of this research it is necessary to perform interventions for the prevention of professional stress with the population of prison officers.

\section{Conclusion}

According to the results, it can be concluded that in facilities of closed type both organisational and operative stressors were much more represented, while the operative stress sources were generally more represented in both groups. The results show their orientation towards lower values, from not stressful to moderately stressful. Sources regarding work appreciation are perceived with a higher intensity of organisational stress, then sources in regard to logistic support and stress sources related to interpersonal relationships in the organisation with the lowest intensity. In higher security facilities total work experience had a moderate positive influence on organisational stressors, and the age of respondents a mild positive effect. Divorced respondents experienced higher intensity of stress. Other sociodemographic factors did not influence stress. "Fatigue", "traumatic event" and "favouritism" were the most important stressors.

\section{Acknowledgements}

I thank to my daughter Ana Suljkanovic for the help with the translation of this article into English.

\section{Conflict of interest}

None.

\section{References}

1. Čabarkapa M. Čovek i radna okolina (psihofiziološki i ekološki aspekti rada). Čigoja štampa. Beograd; 2008. p. 138-184.

2. Law on penitentiary of Republic Srpska (Zakon o izvršenju krivičnih i prekršajnih sankcija Republike Srpske), Official Gazette of Republic Srpska Nr. 64/2001; 24/04, 68/07.

3. Alvarez WC, Stanley LL. Blood pressure in six thousand prisoners and four hundred prison guards. Arch Intern Med 1930;46:17-39.

4. Regan S. Occupational stress and coping among prison officers. An exploratory examination. Greenhouse press. Available from: http://greenhousepress.webs.com/PrisonOfficersOccupationaStress.pdf (last accessed January 10,2020 )

5. Laynay G, Fielding PJ. Stess among prison officers: some empirical evidence based on self report. Howard J Crim Just 1989;28:138-48.

6. Morgan W. Correctional officer stress: a review of the literature 1977-2007. Am Jails 2009;23(2):33-43.

7. Rutter DR, Fielding PJ. Sources of occupational stress: an examination of British prison officers. Work Stress 1988;2(4):291-300.

8. Lambert EG, Hogan NL, Allen R. Correlates of correctional officers job stress: the impact of organizational structure. Am J Crim Justice 2006;30(2):227-46.

9. Sui GY, Hu S, Sun W, Wang Y, Liu L, Yang XS, et al. Prevalence and associated factors of depressive symptoms among Chinese male correctional officers. Int Arch Occup Environ Health 2014;87(4):387-95.

10. Glavina V. Stres u policijskoj profesiji. Policijska sigurnost 2011;20(1):32-46.

11. Finney C, Stergiopoulos E, Hensel J, Bonato S, Dewa SC. Organizational stressors associated with job stress and burnout in correctional officers: a systematic review. BMC Public Health 2013;13:82. Available from:

12. https://bmcpublichealth.biomedcentral.com/articles/10.1186/1471-2458-13-82 (last accessed 15 October 2019).

13. Paoline EA, Lambert EG. The issue of control in jail: the effects of professionalism, detainee control, and administrative support on job stress, job satisfaction, and organizational commitment among jail staff. Am J Crim Justice 2011;37(2):179-99.

14. Hurst TE, Hurst MM. Gender differences in mediation of severe occupational stress among correctional officers. Am J Crim Justice 1997;22:121-37.

15. Lambert EG, Hogan NL, Altheimer I, Wareham J. The effects of different aspects of supervision among female and male correctional staff: a preliminary study. Crim Justice Rev 2010;35:492-513.

16. McCreary DR, Thompson MM. The operational and organizational police stress questionnaires. Available from 
http://www.midss.org/taxonomy/term/27 (accessed 15 March 15 2014).

17. Morgan DR, Van Haveren AR, Pearson AC. Correctional officer burnout further analyses. Crim Justice Behav 2002;29(2):144-60.

18. Sudipto R, Avdi A. The effect of prison security level on job satisfaction and job burnout among prison staff in the USA: an assessment. Int J Crim Justoce Sci 2012;7(2):524-39.

19. Radeta A. Stress with employees of security services of the Prison facility East Sarajevo (Stres kod zaposlenih u službi obezbjeđenja KPZ Istočno Sarajevo). Zbornik radova iz penologije. Penološka organizacija KPZ-a Banja Luka; 2009. p. 134-148.

20. Lambert EG. The impact of job characteristics on correctional staff members. Prison J 2004;84(2):208-27.

21. Rutter DR, Fielding PJ. Sources of occupational stress: an examination of British prison officers. Work Stress 1988;2(4):291-300.

22. Keinan G, Malach-Pines A. Stress and burnout among prison personnel sources, outcomes, and intervention strategies. Crim Justice Behav 2007;34(3):380-39.

23. Konda S, Reichard AA, Tiesman HM. Occupational injuries among US correctional officers, 1999-2008. J Safety Res 2012;43(3):181-6.
24. Corrections Yearbook 2000, 2002 Criminal Justice Institute, Middletown CT. Available from: http://www. maine.gov/dps/mcja/training/mandatory/documents/ h1factsheet.pdf (accessed 15 April 2014).

25. Lambert EG, Paoline EA. The impact of medical issues on the job stress and job satisfaction of jail staff. Punishm Soc 2005;7(3):259-75.

26. Hartley DJ, Davila MA, Marquart JW, Mullings JL. Fear is a disease: the impact of fear and exposure to infectious disease on correctional officer job stress and satisfaction. Am J Crim Justice 2013;38(2):323-40.

27. Lindquist C.A, Whitehead J.T. Burnout, job stress and job satisfaction among Southem correctional officers. J Offender Couns Serv Rehabil 1986;10:5-26.

28. Castle TL. Satisfied in the jail: exploring the predictors of job satisfaction among jail officers. Crim Justice Rev 2008;33(1):48-63.

29. Lambert EG, Hogan NL, Jiang S, Elechi O, Benjamin B, Morris A, et al. The relationship among distributive and procedural justice and correctional life satisfaction, burnout, and turnover intent: an exploratory study. J Crim Justice 2010;38(1):7-16. 